ISSN 2179-345X

Licenciado sob uma Licença Creative Commons

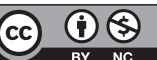

\title{
A filosofia da linguagem na construção de um capitalismo humanista
}

\author{
Language philosophy in the development \\ of a humanistic capitalism
}

\begin{abstract}
Vanessa Hasson de Oliveira
Doutoranda em Direito das Relações Sociais pela Pontifícia Universidade Católica de São Paulo (PUC-SP), Mestre em Direito das Relações Sociais pela Pontifícia Universidade Católica de São Paulo (PUC-SP), Especialista em Direito Ambiental pela Faculdade de Saúde Pública da Universidade de São Paulo (FSP/ USP), Graduada em Direito pela Faculdades Metropolitanas Unidas (FMU), São Paulo, SP - Brasil, e-mail: vanessa.adv@ajusteambiental.com.br
\end{abstract}

\section{Resumo}

As discussões e orientações relativas à preservação do meio ambiente vêm sofrendo uma lenta e progressiva evolução que, entretanto, ainda é bastante superficial. Essa superficialidade é justificada pela diversidade de línguas que operam nessas discussões, por sua própria natureza multidisciplinar, dificultando a conversação. A tradução da problemática econômica em social ou natural ou destas em econômica é impossível, restando como solução a produção de novos conhecimentos, por meio do estabelecimento de uma profunda conversação que possibilite a inauguração de uma nova cultura: aquela da preservação ambiental. O presente trabalho pretende, a partir da filosofia da linguagem, desenvolver 
um raciocínio de aproximação entre as diversas disciplinas que compõem as discussões acerca das questões que envolvem a proteção do meio ambiente, com base na conversação e na poética criadora. Em conclusão, propõe-se a adoção de metodologias cognitivas que tenham por fundamento o alcance do espírito do homem, como forma determinante na mudança de paradigmas e atitudes internas que coincidam com o giro do mundo naturalmente posto.

Palavras-chave: Meio ambiente. Capitalismo humanista. Filosofia da linguagem.

\section{Abstract}

The environmental discussions and orientations are taking slow and progressive evolution however, they are still superficial. This superficiality is justified by the diversity of languages that are involved in these discussions, considering their multidisciplinary nature, which hinders conversation. The translation of the economical problematics into social or natural aspects, or of these into economical factors, is impossible. In the end, the solution is the production of a new kind of knowledge, through a deep conversation that produces a new culture: that of environmental protection. Based on language philosophy, this article intends to approximate the many subjects that are involved in the discussions about protecting the environment, based on conversation and on creative poetics. In conclusion, we propose the adoption of cognitive methodologies that are able to reach the spirit of men, for a definitive change in paradigms and internal actions that coincide with the natural world.

Keywords: Environment. Humanistic capitalism. Language philosophy.

\section{Introdução}

Para Paulo de Barros Carvalho, a teoria geral do direito vem sendo aprofundada com a ampliação de sua abrangência para admitir em sua linguagem dogmática os enunciados de outras ciências, considerando a permanência do modelo de raciocínio da ciência do direito em sentido estrito. Nesse diapasão, o construtivismo lógico semântico 
introduziu mudanças ideológicas importantes no campo epistemológico do direito.

Com muito maior razão, quando tratamos de ramos do direito que requerem, por sua própria natureza, que sejam estabelecidas conversações com outros ramos da ciência, a metodologia do construtivismo lógico semântico presta serviço ainda mais relevante. É o caso do direito ambiental, que regula as relações intersubjetivas entre o sujeito (S) e todos os demais (T). O estabelecimento da conversação entre as linguagens da ciência do direito, filosofia, ciências da terra, antroposofia, sociologia, geografia, geologia, hidrologia, enfim, tantas quantas sejam aplicáveis ao evento social sob incidência normativa, é imprescindível à perfeita eficácia normativa destinada à proteção do bem jurídico planeta Terra.

Num momento anterior, o estabelecimento da linguagem do direito com outras que expressam as ciências humanas proporciona a construção de um direito natural que nos remete a uma percepção de realidade mais próxima da percepção de nosso ser enquanto indíviduos dependentes e interpendentes de todos os seres humanos e demais seres naturais, inclusive do próprio planeta. Essas linguagens, ao dialogarem entre si, produzem novos conhecimentos, fundindo os entendimentos apartados que, para efeito de bens da natureza, podem levar ao cometimento de verdades ilusórias com consequências irreversíveis.

Para que haja a construção de um direito fraterno, que imponha naturalmente sem esforço, a adoção de um capitalismo humanista mais voltado à manutenção de vida digna e da própria vida - o construtivismo lógico semântico -, por meio da filosofia da linguagem, mostra-se como um corte metodológico robusto, conferindo concretude às questões metafísicas que por vezes devem ser introduzidas na produção do conhecimento acerca dos bens naturais.

Paulo de Barros Carvalho defende a filosofia e, mais especialmente, o "giro linguístico" - que ele diz ser a "linha de frente" de uma filosofia da linguagem - como a única forma de se produzir conhecimento científico robusto, incluindo a formulação de uma teoria geral do direito. Com isso, defende que o tom da tradicional retórica jurídica passa a 
figurar em bases mais sólidas e consistentes, unindo o pensamento e as formulações teóricas às experiências concretas da vida.

Dessa forma, o presente estudo toma por base os ensinamentos do professor Paulo de Barros Carvalho sobre a filosofia da linguagem para tecer considerações sobre o resultado das conversações estabelecidas de forma eficiente, em benefício da proteção dos direitos que envolvem a construção de um capitalismo humanista mais congruente com uma vida digna e imprescindível à manutenção da própria vida.

\section{O desenvolvimento sustentável como premissa de um capitalismo humanista}

As discussões sobre a importância da adoção de um modelo mais sustentável do modo de viver já ultrapassaram seus limites linguísticos - estão correndo o risco de virar conversa fiada. O discurso da sustentabilidade já extrapolou a fase de conhecimento: já experimentamos a realidade da insustentabilidade econômica, ambiental e social, e não mais necessitamos aprofundar estudos e obter mais informação acerca do eminente fracasso do desenvolvimento sustentável da humanidade. É chegada a hora de agir!

Vivemos num mundo sistêmico, no qual cada ser natural é interdependente de todos os demais direta ou indiretamente. Cada um de nossos movimentos modifica irremediavelmente o estado de todas e de cada uma das coisas. As modificações do meio ambiente alteram nosso material genético da mesma forma e na exata proporção em que nosso modo de vida altera o meio em que vivemos. O homem é fruto do meio em que vive, e este é resultado dos seres que o habitam. O meio ambiente não é apenas um tema dentro da pauta da sustentabilidade: meio ambiente somos todos nós.

Mais do que perceber, é preciso estar com a cabeça e o coração abertos para constatar que, quer queiramos, quer não, tudo e todos dependem de cada um de nós e de todos nós. Depende de o sujeito facilitar a inserção dos demais seres na sua própria ação, na conversação. 
Biologicamente, a sustentabilidade do desenvolvimento é uma questão natural. O ser humano transforma o ambiente, mas é, da mesma forma, transformado por ele, numa sucessão de ações coordenadas e de coordenações de ações, resultado de processos autopoiéticos que se fundem na criação de novas situações, novos seres, novos conhecimentos, novos conceitos, novos verbos. A sustentabilidade se faz na poesia criadora ensinada por Vilém Flusser, na autopoiese de Humberto Maturana. O equilíbrio da sustentabilidade é inerente à própria manutenção da diversidade da vida. Um conhecido biólogo ilustra a questão da manutenção da vida dizendo: "que me importa se o mundo acabará com a explosão de bombas atômicas fabricadas pelo homem? As bactérias sobreviverão".

Esse equilíbrio da vida é inerente à própria vida. Devemos atenção, então, é com relação a um equilíbrio da vida que proporcione a continuidade da própria vida humana. Não estamos tratando da manutenção da vida do planeta - estamos tratando da manutenção da vida interdependente planetária, da manutenção da vida no planeta, o que inclui a vida do planeta, do ser humano, e dos demais seres da biosfera, com dignidade.

As conversações da atualidade ainda estão voltadas para centros apartados. Falamos da sustentabilidade dos recursos naturais, da melhoria da qualidade de vida do homem, do desenvolvimento econômico sustentável, mas não falamos com igual intensidade, ainda, da manutenção da sustentabilidade naturalmente interdependente da vida. Nesse sentido, Humberto Maturana (2008) propõe o desenvolvimento de uma matriz ética do habitar humano que dialoga com a filosofia da linguagem brilhantemente ensinada por Paulo de Barros Carvalho, já que, para aquele autor, essa matriz conota o entrelaçamento biológico-cultural, próprio dos humanos, com as redes de conversações.

Precisamos da transformação de nossa consciência individual e coletiva, mesmo que aconteça de maneira espontânea, não intencional, como se dá nos processos criativos autopoiéticos. Esse tipo de mudança envolve um processo reflexivo (comunicacional) que nos permite sentir que somos nós mesmos os propagadores da dor e do sofrimento 
que criamos nos outros e em nós mesmos, e que essa criação muito provavelmente está intrinsecamente ligada com aquilo que temos por verdade. Achamos que somos a verdade - a verdade do capitalismo predatório, a verdade do egocentrismo, a verdade do existencialismo, a verdade da dialética.

"E toda experiência de certeza é um fenômeno individual, cego ao ato cognitivo do outro, em uma solidão que, como veremos, é transcendida somente no mundo criado com esse outro" (MATURANA; VARELLA, 1995, p. 253). E o mundo que criamos com o outro é criado por meio das conversações conscientes do amor.

O giro linguísitico foi determinante no despertar dessa consciência para a admissão de uma verdade acima de tudo preenchida desse amor. Paulo de Barros Carvalho, invocando Vilém Flusser, resume o fenômeno: "Descobriremos mesmo que o conhecimento absoluto, a realidade fundamental e a verdade imediata não passam de conceitos não somente ocos, mas também desnecessários para a construção de um cosmos, e que, neste sentido as objeções podem ser aceitas" (MATURANA; VARELLA, 1995, p. 253).

Com efeito, a característica natural biológica de todos os seres, da antroposfera e da biosfera, não se coaduna com a posição do racionalismo dialético, que opõe sujeito e objeto. Trataremos do tema no item seguinte, mas, por ora, importa dizer que na condução de um modo sustentável de vida somos, todos, parte dessa rede de conversações. Estamos, todos, presentes nesse espaço relacional-operacional no qual reside nosso viver e conviver: humanos, árvores, rios, vacas, pássaros, penicilina, bombas atômicas...

Para que a realidade de um capitalismo humanista floresça, é necessário fugir desse dualismo, enfrentar as diferenças linguísticas, estabelecer uma nova conversação, uma conversação rica em poesia. Como nos ensina Humberto Maturana, essa nova consciência é um despertar surgido da rede de conversações que sejam permeadas da emoção do amor. Permeadas, diríamos, da poesia criadora do amor.

Quando grafamos a palavra "amor" com letras destacadas, estamos nos remetendo àquele amor fraternal inaugurado dogmaticamente 
por Jesus Cristo e presente naturalmente nos processos autopoiéticos da Criação, na poesia da linguagem.

Para a doutrina do capitalismo humanista, cujo expoente é o professor Ricardo Hasson Sayeg, a conversação que se estabelece em torno do amor fraterno transmutando-o para além de uma mera virtude moral

para emergir como obrigação jurídica do Estado, da sociedade civil e dos homens livres para com todos e tudo, em especial para com os excluídos sociealmente e para com o planeta - aplicável pelo método quântico, por conta de sua incidência gravitacional trodimensional, sob a ótica do desenvolvimento, da razoabilidade e da proporcionalidade (SAYEG; BALERA, 2011, p. 215).

Esse Estado Fraterno, com liberdade e igualdade, onde todos têm o direito e condições materiais à liberdade e à diversidade biocultural, é um estado que ao mesmo tempo facilita o estabelecimento de redes de conversação sobre a produção e o consumo (capitalismo) e de redes de conversação sobre condições da vida interdependente da antroposfera e da biosfera (humanismo), e ainda facilita o estabelecimento da conversação coordenada entre essas redes de conversação.

A questão da sustentabilidade da produção e do consumo é a princípio um paradoxo, e como tal deve ser submetido ao processo do "giro linguístico" para que seja possível desconstituir essa verdade e inaugurar outra mais próxima da conversação que naturalmente se estabelece na camada humanista da língua.

É certo que, para que haja justificativa para a produção, é necessária uma demanda de consumo, e para que seja possível consumir, de modo a ser possível a manutenção da dignidade da pessoa humana, é imprescindível que haja produção de bens e serviços.

Tratamos, assim, de dois conceitos diversos que se complementam na esfera pragmática, mas que são de origens semânticas diferentes. A produção pode ser conceituada como 
o processo de extrair do mundo natural, através de técnicas e métodos adequados, bens de consumo direto (por exemplo, alimentos) e matéria-prima a ser elaborada ou transformada com vistas à fabricação de outros bens, por procedimentos quer artesanais, quer industriais. À produção de bens acrescente-se a produção ou oferta de serviços, que, quase sempre, demanda o concurso de energia e outros recursos naturais (MILARÉ, 2004, p. 59).

No campo da produção, a questão da sustentabilidade se refere basicamente à utilização racional dos recursos naturais e da matéria-prima da indústria de transformação da produção, além da adoção de tecnologias mais limpas, que produzam menor quantidade de resíduos, que sejam menos poulentes e utilizem menor quantidade de energia. Assim preconiza a Declaração do Rio, da Conferência das Nações Unidas sobre o Meio Ambiente e o Desenvolvimento (1992), em seu princípio 8 diz que para que se possa atingir o desenvolvimento sustentável e mais alta qualidade de vida para todos, os Estados devem reduzir e eliminar padrões insustentáveis de produção e consumo.

No campo do consumo, a tomada de consciência do consumidor, modificando seus hábitos e suas atitudes, pela natureza reflexiva da conversação entre as redes de conversação capitalismo/humanismo, certamente desencadeará uma reação nos modelos dos processos produtivos. Não se trata apenas da diminuição do consumo. O olhar mais humano, o despertar do amor fraternal também operará uma mudança de paradigma definitiva. Afinal, vivemos numa sociedade global onde parte absoluta da riqueza se encontra em poder de uma ínfima minoria, o que representa o consumo desenfreado, desigual e sem a liberdade trazida pelos limites da língua.

O consumismo de poucos representa a fome e a sede de muitos, todos estes, seres humanos iguais em sua igualdade de condição humana. Que língua é essa que fala essa minoria? Ou que limite é esse que essa minoria ultrapassou de uma linguagem humana comum - a linguagem do humano - e que imprime o aprisionamento que nos levará, a todos, à morte solitária? 
É dessa sustentabilidade que devemos tratar quando aproximamos o capitalismo do humanismo. A liguagem do humano, do amor fraterno; aquele que é capaz de preservar a liberdade dos limites impostos pela necessidade de liberdade do outro, que reconhece a igualdade inerente a uma origem comum: o verbo, a autopoiese e a conversação.

É o desenvolvimento sustentável a base metodológica para um capitalismo humanista, a preservação da espécie humana e não humana, a conversação da antroposfera com a biosfera, num contínuo processo de criação poiética.

\section{Aspectos da sustentabilidade na filosofia da linguagem}

Para Vilém Flusser, a língua cria realidade: não há realidade fora da língua, língua é realidade. O ser humano cria sua realidade por meio da apreensão e compreensão de dados brutos (que podem ser palavras). Ao organizá-las, forma frases (articula os pensamentos); externalizando-os, volta a absorver as palavras novamente e, nesse processo circular, surge a língua.

No mesmo diapasão da realidade, o biólogo Humberto Maturana encara a linguagem afirmando que sem ela não há reflexão e, portanto, não há o ser; a única coisa possível fora da linguagem é a digestão - não precisamos pensá-la para que ela seja, assim como não precisamos pensar na linguagem para que ela aconteça. "Quando refletimos sobre a linguagem, já estamos nela” (MATURANA, 2002, p. 38).

O professor Willis Santiago Guerra Filho relembra que a apreensão dos dados brutos nas sociedades primevas era realizada a partir da prática de magia. O ser primevo, assim como o iletrado, se deparam com uma mesma atitude mágica perante as palavras: "A magia pode ser considerada como a forma primeva de pensamento humano" (GUERRA FILHO, 1985, p. 1).

Em sua obra Língua e realidade, Flusser (2004) equipara metaforicamente o Eu a uma árvore. Ensina que o Eu é formado pelo 
intelecto, pelos sentidos e pelo espírito: em relação à árvore, os sentidos seriam as raízes, ligados ao chão da realidade; o intelecto seria o tronco, que transporta a "seiva" da realidade colhida do chão e a transforma, levando-a até o espírito - a copa da árvore - para produzir palavras as folhas, flores e frutos. Podemos nos aproveitar da metáfora para incluir, nessa concepção da mágica da transformação do Eu, que as folhas seriam as palavras, mas os frutos e as flores seriam a oração, o nível mais alto da poesia criadora - da camada superior da língua - e que, tal como as flores e frutos, carregam as sementes da criação. Ainda nos aproveitando da metáfora, a atmosfera seria a camada da adoração, do indizível, região para a qual é expelida a produção da energia da língua por meio da palavra - o oxigênio - e na qual o poeta se inspira em sua poesia criadora, tal qual a árvore se vale do sol e do gás carbônico em seu processo de manutenção da vida.

O elemento utilizado por Flusser é totalmente relacionado ao tema da linguagem, e especialmente de uma linguagem que pretende debater a construção de um capitalismo humanista. Como discorremos no item anterior, somos parte de uma mesma rede de conversação, composta pela antroposfera e pela biosfera. A árvore de Flusser é mais uma prova disso. O sistema comunicacional dos dois elementos é bastante aproximado.

Quando o intelecto se lança na apreensão de dados brutos, o faz na forma de palavras: ele passa a armazenar palavras, a organizá-las em frases - formando pensamentos -, reorganizá-las e transportá-las para o espírito, produzindo, assim, a língua, e produzindo também sua própria realidade e a realidade do mundo que o cerca.

Na biologia de Maturana e Varella, a língua-realidade de Flusser é perfeitamente enquadrada, na medida em que

encontramos a nós mesmos nesse acoplamento, não como a origem de uma referência, nem em referência a uma origem, mas sim em contínua transformação no vir-a-ser do mundo lingüístico que construímos com os outros seres humanos (MATURANA; VARELLA, 1995, p. 253). 
Flusser segue na constatação de que o intelecto sente a diferença entre absorver uma palavra ou um dado bruto, colhidos do chão da realidade: quando absorve uma palavra, é instaurada uma conversa; quando se trata de um dado bruto, o intelecto articula.

A conversação pressupõe uma mensagem anteriormente articulada, que contém todas as impressões e emoções do emissor, estando, assim, "contaminada" de elementos secundários que podem resultar ou na impossibilidade de apreensão do significado, por simples repulsa, ou numa apreensão e compreensão equivocada da intenção original. Surgem os ruídos de comunicação.

Tendo isso em mente, as mensagens de "estímulo" à produção e consumo sustentáveis talvez devam ser produzidas de modo a atingir diretamente o espírito ou serem articuladas a partir de dados brutos diretamente.

Maturana trata da questão quando discorre sobre a tomada de consciência não intencional, à qual nos referimos anteriormente. Trata-se de um experimentar biológico-cultural do ser humano.

Paulo de Barros Carvalho nos ensina que para a semiótica o termo "comunicação" designa qualquer processo de intercâmbio de uma mensagem entre um emissor e um receptor, na seguinte esquematização: emissor - canal - mensagem - código - receptor - conexão psicológica, sendo que o emissor e o receptor devem possuir em comum, ao menos parcialmente, o repertório necessário para a decodificação da mensagem.

Flusser diz que existem basicamente três tipos de línguas: as flexionais, as aglutinantes e as isolantes. Considerando a língua realidade, um universo onde se estabelece a comunicação, podemos trazer à baila novamente a questão da sustentabilidade para pôr em conversação os três pilares do desenvolvimento sustentável, ou seja, os três tipos de mundo dentro dos quais o intelecto humano vive: o ambiental, o social e o econômico.

É possível, também, levantar o problema da tradução entre esses mundos. Existe uma impossibilidade clara no estabelecimento de uma conversação entre esses três pilares da sustentabilidade: tratam-se de linguagens distintas, de universos distintos, assim como se dá entre 
as línguas orientais e ocidentais. A princípio, emissor e receptor não possuem o mesmo repertório para a decodificação da mensagem. A tradução é o método que possibilita a tentativa do estabelecimento de conversação entre os três mundos.

Para Flusser, a tradução não existe. Toda tradução implica a morte do texto original e, em consequência, o nascimento do texto traduzido. Para cada um de nós, a realidade reside em sua própria língua materna, sendo todas as outras instrumentos de aproximação da realidade. Essa aproximação, contudo, permite ao intelecto superar os horizontes da língua, podendo ser mais próxima, quanto mais próxima for a semelhança ontológica entre as línguas.

Voltando ao tema dos três universos da sustentabilidade, seria possível estabelecer uma conversação entre os mesmos? Pertencem eles a um mesmo idioma ou será necessário realizar a aproximação por meio da tradução? São questões que serão mais bem desenvolvidas nos itens posteriores.

Na tentativa de superar o problema da tradução e dos ruídos da comunicação, Flusser cogita a hipótese do desenvolvimento de uma língua original hipotética, mas logo a abandona, ainda que reconheça um traço comum. Então, devemos admitir a conversação precária. Nesse aspecto, para o tripé da sustentabilidade, existe um traço comum identificável: o planeta Terra e tudo o que ele significa, o primeiro ser vivente de nosso sistema antroposfera-biosfera. Será possível, então, no caso dos universos distintos que compõem a sustentabilidade, o estabelecimento de uma língua comum?

A filosofia e, em especial, a filosofia da linguagem nos dão a esperança de promover por meio da conversação um entendimento maior entre os seres da rede de conversações do planeta, considerando o entendimento do filósofo de que uma filosofia consciente de si mesma seria uma conversação que tem por tema essa própria conversação. A conversação seria o conversado. A conversação cria uma nova realidade. Quiçá a criação da realidade de um direito fraterno. 
Analogamente, o entendimento das questões da sustentabilidade, entendida como premissa do capitalismo humanista, deve ser realizado por meio do estabelecimento de uma conversação sobre a conversação que se opera entre seus três pilares. Daí a importância da interdisciplinaridade e da intertextualidade, à qual aprofundaremos em tópicos posteriores.

Flusser escolheu a língua portuguesa como um terreno neutro, que possibilita traduções e retraduções, proporcionando alguma vantagem às conversações. Talvez pudéssemos, da mesma forma, estabelecer um terreno neutro - uma disciplina neutra - dentre as várias disciplinas que se dispõem à troca interdisciplinar.

Contudo, a conversação precisa ser estabelecida, evitando-se a conversa fiada (Heidegger) ou o silêncio definitivo (Wittgenstein). Ludwig Wittgenstein, um dos principais nomes da filosofia da linguagem, disse que o mais fundamental não podia ser dito. No entanto, até que possamos estabelecer essa condição para a solução do caos ambiental, muitas conversações ainda deverão ser travadas. Deixemos o indizível para o momento das orações pela paz e harmonia no planeta. Ainda temos um caminho longo pela frente até que uma consciência coletiva humanista prevaleça em sintonia no indizível comum.

De outro lado, algumas conversas aparentes podem ser até intituladas de conversa fiada e na verdade realizarem uma diferença importante na conversação dessa rede de conversações planetárias. Esses aparentes fiados de conversa, na verdade, consubstanciam-se em saberes em conversação. Podem ser realizados numa feira livre, num encontro furtivo em um espaço público. Definitivamente não farão parte de um processo elaborado e muito menos da ciência, mas têm importância fundamental na rede de conversações que se estabelecem em âmbito interdisciplinar. O que importa é que, ao contrário da conversa, na conversação os intelectos participantes estão em contato um com o outro, são abertos um para o outro, estão juntos. Na conversa o clima é o oposto, os intelectos estão fechados, não absorvem a informação, não apreendem e não compreendem nada. Produzem, se é que se pode chamar isso de 
produção, mensagens distorcidas e deturpadas. A conversa fiada aprisiona os intelectos dentro de informações que os circundam. Os intelectos ficam determinados pelas coisas. Uma grande parte da humanidade talvez seja assim.

Retomando a questão da insustentabilidade dos modos de produção e consumo atuais, cuja contribuição é sobremaneira perpetrada pelos consumidores de forma reflexa à produção, a conversa fiada do marketing deturpado, de estímulo ao consumismo, aprisiona esse consumidor e o torna incapaz de apreender e compreender a essência de sua participação individual na rede de conversações em torno do problema. É preciso retomar a conversação.

Em contraponto à conversa fiada, na teoria de Flusser reside, no extremo oposto da língua, a poesia. Analogicamente à filogênese das espécies biológicas, a poesia é uma mutação da conversação. Funcionalmente, a poesia é a criação de nova língua a partir do nada que cerca a língua de todos os lados. Esse nada é o caos que vive em potencialidade sistemática, pronto a eclodir em organização sistemática, como no princípio de tudo. Trata-se do caos que cerca a realidade por todos os lados.

A natureza é matéria-prima para a atividade poética à conversação. A civilização é natureza transformada. Dado o estado de evolução vertiginosa da produção de informações por meio das conversações, a impressão é de que a natureza do primeiro grau se esgotou, e que a conversação retoma sua atividade num grau secundário. Surge o sentimento de frustração, o nojo existencial, que caracteriza parte da conversação atual e ameaça degenerá-la em conversa fiada. É preciso retomar a conversação com poesia.

Flusser ensina, ainda, que na camada da conversação a natureza é transformada em civilização e assim se expressa - expelida do tecido da língua. Isso demonstra que a civilização é o excremento e a natureza, o conteúdo, a matéria-prima. Ao ser expelida, a civilização deixa de fazer parte da língua, da realidade. É preciso retomar a realidade, é preciso retomar o início, a atividade poética. 


\section{Interdisciplinaridade e novos saberes}

Sendo a conversação, considerada em toda a sua estensão, a forma como a língua cria uma nova cultura, para o desenvolvimento das ciências é imprescindível que essa conversação se realize com ampla participação de todas as disciplinas envolvidas.

A interdisciplinaridade em matéria de desenvolvimento sustentável, pode-se dizer, é a que contempla maior número de disciplinas em sua participação, desde a física até as artes cênicas. Quando é possível desenvolver uma questão interdisciplinar de modo interdisciplinar, produzimos a aproximação das línguas das diversas disciplinas envolvidas, estabelece-se a conversação e cria-se uma nova cultura que permite a resolução da questão, contemplando todas as suas nuances.

Contudo, quando se trata da ciência jurídica, essa nova cultura deve ser retraduzida para a linguagem dogmática, naquilo que conhecemos por modelo de raciocínio da ciência do direito em sentido estrito. Nesse sentido Paulo de Barros Carvalho sentencia que é possível trazer ao discurso jurídico sentenças da economia, da ciência política, da sociologia, da história, da antropologia, mas apenas para ajudar no esclarecimento, "para servir de contraste, de pano de fundo, jamais para fundamentar o modo de ser peculiar do pensamento jurídico" (MATURANA; VARELLA, 1995, p. 158).

Em termos de resolução de problemas humanos mais viscerais, como é o caso da fome, das mudanças climáticas, ou da escassez de água potável no mundo, acreditamos que esse pano de fundo passa a ter outra dimensão. Nesses casos, é o direito em sentido estrito que se curva para que a ciência do direito, a partir da filosofia, ultrapasse o dogmatismo e abra os caminhos para a conversação com as outras disciplinas.

A experiência que vivemos nos dias de hoje, da constatação de que pessoas ainda morrem de fome e de sede, de que temos os dias contados para o início das catástrofes originadas pelos efeitos do aquecimento global, e para o fim da água potável no mundo, é matéria-prima para as 
ciências que estudam esses mesmos males da humanidade. Isso quer dizer que não precisamos de nenhuma disciplina, nenhuma ciência específica para nos fazer enxergar a realidade que se coloca aos nossos olhos e peles desnudados. Vemos, se não pessoalmente, mas pelos meios de comunicação visual, as pessoas desfalecendo em ossos de fome, sentimos calor e os efeitos da confusão das estações do ano em nossa própria pele, e, com isso, temos participação, ainda que involuntária, na constituição dessa nova cultura de um capitalismo humanista.

Paulo de Barros Carvalho assevera, nesse sentido, que não existe um fato puro; toda a ciência dialoga com a experiência que é realizada nas mais diversas vertentes por onde navega o espírito humano. Com brilhantismo, o professor preleciona: "Isso impede a construção do 'fato puro', seja ele econômico, histórico, político, jurídico ou qualquer outra qualidade que se lhe queira atribuir" (MATURANA; VARELLA, 1995, p. 158).

Em matéria ambiental, a interdiscipinaridade proporciona a conversação entre a natureza e a civilização, entre as ciências naturais e as ciências do espírito.

Aqui reafirmamos que quando se trata de meio ambiente (e agora devemos considerá-lo na sua acepção real - meio ambiente somos nós), quando se trata da conversa que vem se operando nessa rede de conversação e que se encaminha para o nada, o caos, não é possível admitir que apenas parte da rede participe da conversação. É preciso ampliar e aprofundar a conversação, incuindo a prática da interdisciplinaridade junto com as ciências naturais e sociais, uma conversação de saberes.

Willis Santiago Guerra Filho trata da interdisciplinaridade como noção de unidade do saber ou "perspectiva integradora" e diz que ela vem predominando em epistemologia,

superando os últimos resquícios metafísicos e teológicos presentes na perspectiva objetivista, analítica e reducionista das ciências em seus primórdios, que, de maneira triunfalista, difundiam a crença na definitividade dos conhecimentos por meio dela obtidos, por baseados na 
observação de regularidades que permitiam elaborar leis gerais explicativas (GUERRA FILHO, 2009a).

Refere-se à derrocada da física mecanicista para a admissão da física quântica e inauguração de uma teoria de sistemas.

Como veremos, a interdisciplinariedade está alinhada com a resposta conclusiva do presente estudo, de que é na conversação realizada conforme a natural disposição sistêmica de todas as coisas do universo (incluídos os sujeitos), que reside o caminho para a paz e harmonia do Planeta. Enrique Leff, em estudo aprofundado sobre o tema, sobre o qual se dedica, conclui:

se a questão ambiental demanda uma resignificação do mundo e a reapropriação da natureza, a partir de um questionamento das formas de conhecimento e apropriação que produz a ciência moderna, ela significa uma revisão das formas "não científicas" de compreensão do mundo", das relações do homem com a natureza. Quer dizer, não se trata somente da integração natureza-sociedade por meio da inter-relação das ciências, senão da abertura para um diálogo de saberes, para a hibridização entre as ciências, tecnologias e saberes, para a produção de novos paradigmas de apreensão do real e comunicação entre saberes, do encontro entre a epistemologia e a hermenêutica (CARVALHO, 2000; LEFF, 2000; VATTIMO, 1992 apud GUERRA FILHO, 2009b).

A conclusão de Leff nos remete à poesia da língua de Flusser. Os novos paradigmas de apreensão do real devem estar calcados no estímulo à produção da poesia numa atividade filogênica da conversação. É preciso estimular a mutação da conversação para a produção de novos saberes, e que sejam eles hibridizados, compondo em harmonia os aspectos do ambiental, do social e do econômico.

Essa mutação da poesia é também uma mutação dos valores. Por meio dos valores, damos sentido às coisas, e é o sentido que nos leva a intervir e transformar a naureza. Acabamos nos envolvendo, remexendo essa rede de conversações, temperada pela práxis social, na ânsia de 
satisfazer nossas necessidades e no retorno das necessidades naturais do equilíbrio sistêmico, e nos esquecemos de abrir a conversação para todos os nodos da rede.

\section{Conversações para a apropriação do capitalismo humanista}

Antes de adentrar ao tema proposto propriamente dito neste capítulo é necessário estabelecer de que capitalismo humanista estamos tratando.

O capitalismo é um sistema econômico marcado pela livre apropriação dos bens da natureza e distribuição dos lucros advindos da produção de bens e consumo, possibilitados por aquela apropriação. O humanismo é a filosofia que coloca o homem e seus valores morais como centro de todas as coisas. Assim, numa definição bastante superficial, poderíamos considerar um capitalismo humanista como a disciplina que pretende introduzir todos os valores morais inerentes ao homem no processo de desenvolvimento capitalista.

O desafio que se apresenta nessa conversação vem ainda posteriormente a outro, aquele debatido nos parágrafos anteriores, que revela a posição do homem enquanto mais um membro da rede de conversações do planeta Terra, em situação de igualdade diante dos demais seres e dos elementos que com ele realizam a realidade de forma interdependente. Daí que o aprofundamento do conceito (precário) do capitalismo humanista formulado anteriormente deva receber a água limpa jorrada dos ensinamentos do professor Ricardo Hasson Sayeg, que define introduz a filosofia humanista do Direito Econômico que estamos abordando como "o transporte teórico da Lei Universal da Fraternidade para o Direito Econômico, o que ora se propõe e que certamente constitui um novo marco teórico de análise jurídica do capitalismo - cujo objetivo declarado na seara econômica é, então, resolver por meio da fraternidade, levando-se em conta as três dimensões subjetivas dos direitos humanos, a tensão dialética entre a liberdade e a igualdade (SAYEG; BALERA, 2011, p. 25). 
Com efeito, assevera Guerra Filho que essa postura dicotômica entre sujeito e objeto está ultrapassada. Ele diz que a visão do humanismo da modernidade deve ser desumanizada, pois o apartamento entre os seres humanos e seu meio ambiente natural pode ser a coluna central da crise epistemo-ecológica.

Sendo assim, a proposta do capitalismo humanista é

entender e reger o capitalismo através de um olhar humanista antropofilíaco - que exige a concretização dos direitos humanos em todas as suas dimensões -, tendo por fim enlaçar a economia de mercado com a consecução, da melhor forma possível e de acordo com a realidade, do direito objetivo da dignidade da pessoa humana e do planeta, edificando a sociedade universal fraterna (SAYEG; BALERA, 2011, p. 215).

Ambas as definições do professor Ricardo Sayeg são carregadas de elementos que transcendem as Ciências. Trata-se de pura poesia. Buscam na essência da vida, no aspecto mais pragmático do amor - a fraternidade -, a substância de ligação para a manutenção do entrelaçamento da rede planetária.

Essa chamada lei universal que já foi defendida como o princípio do não contraditório de Deus, parte do fato de que toda a Criação pressupõe a manutenção da vida, e para tanto, tudo que é criado permanece irmanado na troca dessa essência como método inerente, natural.

A chamada do capitalismo humanista quer apenas relembrar essa condição. Grita num chamado surdo, próprio das coisas pertencentes ao Indizível, que somente podem ser entendidas na apreensão direta pelo espírito, por meio da emoção do amor. Com efeito, Humberto Maturana (2002, p. 90) ressalva que as palavras projetam a realidade, mas que "o domínio em que se realizam as ações que as palavras coordenam não é sempre claro num discurso, e é preciso esperar o devir do viver para sabê-lo".

Significa dizer que não basta a intelecção das palavras ditas e escritas de forma tão brilhante pelo professor Ricardo Sayeg. A apreensão, a compreensão, pelo intelecto humano - já bestificado e aprisionado pela conversa fiada e a salada de palavras que o aprisiona - somente se 
realizará pelo amor. Aquele amor bíblico de 1 Coríntios, capítulo 13, que está acima da própria fé. Um amor que não procura um objeto de referência; um amor que existe por si mesmo; que transcende; aquele amor do Buda Iluminado. O amor que Jesus Cristo viveu. Somente tal natureza de sentimento é capaz de transformar o pensamento humano atual. Não queremos dizer com isso que se trata de missão impossível; ao contrário, basta um átimo dessa emoção para adentrarmos o caminho da compreensão de nosso papel humano no Planeta.

Essa lei universal, esse sentimento de amor, é fundamento para a conversação do capitalismo humanista, como modo de (re)estabelecimento de uma forma mais harmônica de viver. O capitalismo humanista toma por fundamento a lei universal da fraternidade,

com foco no poder simbólico de Jesus Cristo; porque, como Ele ensinou e está cientificamente demonstrado, mais do que iguais, somos irmãos, uma vez que estamos conectados a um elemento comum, a partícula de Deus, reconhecida pela física quântica e cosmologia na teoria do Big-Bang; como também, pelo naturalismo a partir de Darwin (SAYEG, 2008, p. 29).

Ainda para a biologia, o amor é identificado como a emoção que nos possibilitou em nosso evoluir histórico o consenso na troca, nas coordenações das interações que resultaram (e deve resultar) em nosso cosmos comum. Confira-se nesse sentido, as lições de Humberto Maturana (2002, p. 14):

ao surgir assim, os seres humanos surgem num conviver em redes de conversações que em seu devir histórico se constituem nos distintos mundos que habitam como diferentes âmbitos de sentires e fazeres sensoriais-emocionais que se realizam de modo espontâneo no transfundo fundamental do conviver no amar. 
Willis Santiago Guerra Filho nos dá base epistemológica da filosofia do direito para permitir a afirmação metafísica que realizamos anteriormente:

tal concepção impede que se trace uma linha de demarcação muito rígida entre os diversos saberes, o que se nos afigura mais uma nota de grande atualidade do pensamento ora apresentado: mais uma vez vem-nos à lembrança Karl Popper, quando em texto clássico nega que haja critérios para uma demarcação rigorosa entre os domínios da ciência e da metafísica (GUERRA FILHO, 2009a).

E para dar completude e mais concredute a esse coro, lembramos que Paulo Barros Carvalho afirma a ocorrência do conhecimento:

mediante qualquer das modalidades formais de consciência: a percepção, a sensação, a lembrança, as emoções... o objeto é aprisionado por atos competentes, mas, por uma série de motivos sobre os quais especula a psicologia individual, ele permanece latente, oscilando em camadas inferiores do nosso espírito, que poderíamos chamar de "saberes inconscientes" (CARVALHO, 2008, p. 12).

Junto com tais ensinamentos, elucidamos que, com efeito, a emoção do amor, ainda que latente, é a forma correspondente para a apreensão do objeto capitalismo humanista, do qual estamos tratando.

Vilém Flusser (2004) lembra uma história que ilustra o "progresso" da ciência em apartamento da lei universal da fraternidade, citada por Whitehead, que conta: um cientista náufrago numa ilha deserta descobre uma pegada na areia. Com seus métodos exatos reconstrói o ser que causou a pegada e descobre ter sido esse ser ele mesmo. Ora, isso é exatamente o retrato do homem atual que se perdeu do amor próprio, de si mesmo, e da rede de conversações à qual pertence; que o faz cego e insensível às manifestações da natureza, de sua própria natureza humana. A natureza é algo a ser vivido ao invés de compreendido. De outra forma, adotaremos 
implicitamente o conformismo daquele famoso biólogo, para quem não importa se bombas atômicas explodirão, destruindo o universo; afinal, as bactérias sobreviverão. O sistema reiniciará sua ordem, retomando o processo autopoiético que é amor em uma de suas formas mais puras.

Trata-se ainda de questão de justiça. Por força da tradição aristotélica, a justiça sempre foi encarada como conceito relacional, tendo por núcleo a igualdade proporcional - no agir justamente existe equilíbrio entre as coisas e entre as coisas e as partes. A filosofia kantiana (fundamento e a metafísica dos costumes) nos permite uma outra aproximação do conceito de justiça, na qual a vontade (valor) cede lugar à ação necessária em si mesma; contudo, é o ser humano a finalidade última, sempre na posição de sujeito, nunca como objeto.

Com a devida vênia, ao admitirmos tal assertiva, e tendo em vista a extensa argumentação de nossa posição humana em pé de igualdade na manutenção da vida, na construção de um capitalismo humanista, assim como o ser humano se apresenta como objeto sui generis, o Planeta se apresenta como sujeito sui generis. É na utilização desse senso de justiça que reside um dos entraves centrais dessa nova cultura do amor.

A ciência do direito quer aproximar-se da camada social, mas como não pode tocá-la se vê impedida do acesso ao verdadeiro significado da lei universal da fraternidade. Não pode vivê-la, pois, em seu dogmatismo, não admite a linguagem fora do direito. Não pretendemos com isso negar o Estado de direito. Consideramos a possibilidade de um direito fraterno, uma ciência do direito que, ao lado dos princípios da segurança jurídica e da justiça, ponha em pé de igualdade o amor fraternal. Acreditamos que a linguagem do direito em sua função pragmática prescritiva de condutas é capaz de alterar o comportamento humano, servindo de estímulos, com seu aparato coativo ou não coativo mas incentivador, tendo por pressuposto as lições do professor Paulo de Barros Carvalho acerca das formas de apreensão do conhecimento.

Assim, são diversas as curiosas normas jurídicas de incentivo à adoção de algo inerente à manutenção da vida humana. Tomemos como 
exemplo a recentíssima Política Nacional de Mudanças Climáticas, introduzida sob a égide da Lei n. 12.187, de 29 de dezembro de 2009, que trata em seu artigo $5^{\circ}$ das diretrizes da referida Política, incluindo aí, em seu inciso XIII, alínea b: "o estímulo e o apoio à manutenção e à promoção de padrões sustentáveis de produção e consumo”.

No plano das conversações da rede de conversações do Planeta, os padrões sustentáveis de produção e consumo são valores fundamentais à própria existência. Na verdade, produção e consumo são línguas de um mundo diferente da língua sustentabilidade e, tal como o capitalismo humanista, merecem aprofundamento e ampliação de seus conceitos para que seja possível o estabelecimento de uma conversação, caso contrário a norma supratranscrita será letra natimorta. Humberto Maturana acredita que essa conversação poderá resultar numa mudança de paradigma dos fatores-chave que compõem o problema dos modos mais sustentáveis de produção e consumo:

dado que as assim chamadas necessidades humanas fundamentais de uma pessoa num olhar desde nossa cultura patriacal matriarcal, pertence a uma sociedade distinguida como consumista seriam as mesmas de uma sociedade distinguida como ascética; o que mudaria seria o tipo de meios empregados para sua realização (satisfatores) (MATURANA, 2002, p. 92).

Tendo isso em mente, as mensagens de "estímulos" à produção e ao consumo sustentáveis talvez devam ser produzidas de modo a atingir diretamente o espírito ou serem articuladas a partir de dados brutos diretamente. Maturana e Carvalho tratam da questão quando discorrem sobre a tomada de consciência não intencional, à qual nos referimos anteriormente. Trata-se de um experimentar biológico-cultural do ser humano que pode ser realizado tanto com as atividades da práxis social quanto com o sofrimento advindo das intercorrências ambientais que acabam por se configurar em grandes oportunidades de apreensão e compreensão da mensagem do caos ambiental.

Nesse sentido, as mudanças climáticas (mais do que as imagens de seres humanos morrendo em ossos em decorrência da sede e da fome, 
isentas de uma proximidade concreta, sensitiva, egocêntrica e egoísta) se mostram como uma dessas oportunidades, pois evidenciam um tempo cronológico para a tomada de consciência ou a própria morte, fora do discurso meramente retórico até então existente.

\section{Considerações finais}

Retornando às questões propostas com relação ao tema dos três universos da sustentabilidade (ambiental, social, econômico), seria possível estabelecer uma conversação entre eles? Pertenceriam eles a um mesmo idioma ou seria necessário realizar a aproximação por meio da tradução?

A menos que possamos identificar uma linguagem comum, a linguagem planetária, aquela que o professor Ricardo Sayeg identificou com lei universal, não será possível estabelecer essa conversação, pois a tradução, tal como tem demonstrado, gera deturpações e distorções da mensagem.

O universo ambiental diz sede e o econômico entende produção; o social diz fome e o ambiental entende biodiversidade; o econômico diz matéria-prima e o social entende lucro.

É preciso constituir-se uma nova linguagem; uma linguagem que remonte aos primórdios, ao início da rede; que identifique o ponto de encontro das estruturas de tudo quanto tenha sido criado no Planeta. Para tanto, é necessário encontrar os caminhos de estímulo à promoção dos encontros das estruturas que hoje são diferenciadas, proporcionando nesse encontro sua interação, para o surgimento de uma nova ordem.

Acompanhemos o que ensina a respeito Humberto Maturana (2002, p. 59):

a linguagem se constitui quando se incorpora ao viver, como modo de viver, este fluir em coordenações de conduta que surgem na convivência como resultado dela - quer dizer, quando as coordenações de conduta são consensuais. Toda interação implica num encontro estrutural entre os que interagem, e todo encontro estrutural resulta num desencadilhamento ou num desencadeamento de mudanças estruturais 
entre os participantes do encontro. O resultado disto é que, cada vez que encontros recorrentes acontecem, ocorrem mudanças estruturais que seguem um curso contingente com o curso desses. Isto acontece conosco no viver cotidiano, de tal modo que, apesar de estarmos, como seres vivos, em contínua mudança estrutural espontânea e reativa, o curso de nossa mudança estrutural espontânea e reativa se faz de maneira contingente com a história de nossas interações.

Willis Santiago Guerra Filho vê no resgate da magia da "naturalidade" das sociedades primitivas um possível caminho:

a passagem do modo de organização social para um estágio onde se perde a relação mágica com o ambiente, substituída pelo império da religião e dos deuses voluntariosos, com poder absoluto sobre a sucessão dos eventos, representa também o fim de uma sociedade igualitária, possuidora de uma ordenação jurídica dotada de algo que bem se pode chamar "naturalidade". É quando se instaura igualmente a "rebelião" contra a Natureza, da qual o homem não se concebe mais como parte, passando a tomá-la como objeto de conquista e exploração. Surge, então, uma estrutura de poder que submete a grande maioria aos desígnios de poucos, dentre os quais sempre estiveram os detentores do "monopólio do sagrado", institucionalizado em religiões. A convicção da necessidade atual de se ingressar em outro estágio de organização social, menos predatória em relação aos seus próprios membros e à Natureza, leva à busca de renovação das formas jurídicas, para o que muito pode contribuir a pesquisa e reflexão sobre o Direito que é natural ao homem, em seu modo primevo de se organizar socialmente (GUERRA FILHO, 1985, p. 12).

De qualquer forma, a resposta estará no estabelecimento de uma conversação, como entrelaçamento da emoção fraternal. "De fato, nossa única possibilidade de viver o mundo que queremos viver é submergirmos nas conversações que o constituem, como uma prática social cotidiana, numa contínua co-inspiração ontológica que o traz ao presente" (MATURANA, 2002, p. 91).

Afinal, somos como somos em congruência com nosso meio, e nosso meio é como é em congruência conosco, e quando esta congruência 
se perde, não somos mais (MATURANA, 2002, p. 63). Enquanto houver adoração, emocionará; enquanto houver poesia, criará; enquanto houver conversação, permanecerá.

Em conclusão, a menos que possamos identificar uma linguagem comum, a linguagem planetária, aquela, não será possível estabelecer essa conversação, pois a tradução, tal como tem demonstrado, gera deturpações e distorções da mensagem.

A resposta para o novo paradigma de inter-relação entre o ser humano e o seu ambiente natural está no estabelecimento de uma conversação, como entrelaçamento da emoção fraternal. Somos o que conversamos e é em função dessa conversação que nossa cultura se estabelece.

Assim, para que seja possível o estabelecimento de padrões sustentáveis de produção e consumo, devem ser implantadas políticas públicas de educação ambiental formal que tomem por base a linguagem produzida a partir da emoção.

\section{Referências}

CARVALHO, P. de B. Direito tributário, linguagem e método. 3. ed. São Paulo: Noeses, 2008.

FLUSSER, V. Língua e realidade. 2. ed. São Paulo: Annablume, 2004.

GUERRA FILHO, W. S. Direito e magia. Revista da Faculdade de Direito, Fortaleza, v. 28, n. 2, p. 155-169, 1985.

GUERRA FILHO, W. S. Biologia e epistemologia. São Paulo, 2009a. Mimeo.

GUERRA FILHO, W. S. Ética, ciência, direito e teoria de sistemas (em face da crise paradigmática e ecológica). São Paulo, 2009b. Mimeo.

LEFF, E. Complexidade, interdisciplinaridade e saber ambiental. In: PHILIPPI Jr., A. et al. (Ed.). Interdisciplinaridade em ciências ambientais. São Paulo: Signus, 2000. p. 19-51. 
MATURANA, H.; VARELLA, F. A árvore do conhecimento: as bases biológicas do entendimento humano. Campinas: Psy II, 1995.

MATURANA, H. Emoções e linguagem na educação e na política. Belo Horizonte: Ed. da UFMG, 2002.

MATURANA, $H$. et al. Matriz ética do habitar humano: entrelaçamento de sete âmbitos de reflexão-ação numa matriz biológico-cultural: democracia, pobreza, educação, biosfera, economia, ciência e espiritualidade. 2008. Disponível em: 〈http://escoladeredes.ning.com/group/bibliotecahumbertomaturana〉. Acesso em: 28 jan. 2011.

MILARÉ, É. Direito do ambiente. 3. ed. São Paulo: Revista dos Tribunais, 2004. SAYEG, R. H. O capitalismo humanista no Brasil. In: SILVA, M. A. M. da; MIRANDA, J. (Org.). Tratado luso-brasileiro da dignidade humana. 2. ed. São Paulo: Quartier Latin, 2008. p. 1355-1370.

SAYEG, R. H.; BALERA, W. O capitalismo humanista. Petrópolis: KBR, 2011.

Recebido: 30/03/2011

Received: 03/30/2011

Aprovado: 20/05/2011

Approved: 05/20/2011 